\title{
DIFFERENCES OF PREMENSTRUAL SYNDROME PREVENTIONS BEFORE AND AFTER THE FOOD CONSUMPTION WHICH CONTAINS ISOFLAVON IN ADOLESCENT
}

Ni Wayan Putri Utam, S. Tr., Keb.i ${ }^{1}$ Ida Sofiyanti, S.Si.T., M.Keb ${ }^{2}$, Galeh Septiar Pontang, S.Gz., M.Gizi ${ }^{3}$

${ }^{1}$ Prodi D IV Midwifery, Faculty of Health Sciences, Ngudi Waluyo University, Semarang, Indonesia

${ }^{2}$ Prodi D IV Midwifery, Faculty of Health Sciences, University Ngudi Waluyo, Semarang, Indonesia

${ }^{3}$ Prodi Gizi, Faculty of Health Sciences, Ngudi Waluyo University, Semarang, Indonesia

\section{SUBMISSION TRACK}

Recieved: 21 Mei 2018

Final Revision: 2 Juni 2018

Available Online: 30 Juni 2018

\section{KEYWORDS}

Isoflavone, premenstrual syndrome

CORRESPONDENCE

Phone: +628786214 4354

E-mail: niwayanputriutami1@gmail.com

\section{A B $\mathbf{S}$ T R A C T}

In adolescence, there will be some complaints, such as complaint of premenstrual syndrome (PMS). It defined as a physical, psychological or emotional symptom that appeared 7-10 days before menstruation. One of the treatments to reduce premenstrual syndrome is to eat food that contains isoflavones (68mg / day) because it has antiestrogenic effect which is able to balance progesterone and etherogen hormones, which can decrease the complaints of premenstrual syndrome. This study aimed to determine the premenstrual syndrome complaints before and after the consumption of isoflavone food in tenth grade adolescents in Senior High School 2 Ungaran.

This study was using pre-experimental design with one group pretest-posttest study design using simple random sampling totaling 16 respondents. Measurement of complaint of premenstrual syndrome used Premenstrual Shorted Assassement Form 1-6. Data analysis was performed using bivariate analysis using Paired-T test.

Results of this study shown that 16 respondents who had complaints of premenstrual syndrome before the consumption of isoflavones food that contained isoflavones 14 respondents had moderate complaints and 2 respondents had light complaints. After the consumption of isoflavone food it showed that 9 respondents had moderate complaint and 7 respondents had light complaint. Based on statistical test, it was found that the mean value decreased from 26.18 to 21.12 , the median from 15.00 to $21.50, S D \pm 5.706$ to \pm 3.51 with $p$ value of 0.011 , which means $p$ value $<0.05$. Conclusion of this study that there are differences in the complaint of premenstrual syndrome before and after the consumption of isoflavone food in tenth grade adolescents in Senior High School 2 Ungaran. 


\section{INTRODUCTION}

Premenstrual syndrome is a set of complaints of physical, emotional, and behavioral symptoms that occur in reproductive women, which appear cyclically within seven to 10 days before menstruation and disappear after menstrual blood comes out that occurs in a levels that influence lifestyles and activities (Suparman and Ivan, 2011). Factors suspected to be the cause of premenstrual syndrome include low levels of the hormone progesterone and excessive estrogen levels before menstruation (Suparman, 2010).

According to researchers from the American College of Obstetric and Gynecologist, premenstrual syndrome is caused by an imbalance between estrogenprogesterone hormone pairs influenced by psychological factors, activity factors and food consumption factors. Journal of America Science in 2011, says premenstrual syndrome occurs in $70 \%$ of women in reproductive and about $30-80 \%$ of women havesymptoms premenstrual syndrome moderateand about $2.5 \%$ of women experience premenstrual syndrome with severe symptoms (Jurgen, 2009).

Based on data obtained from UKS data from January to December 2016, there were $51 \mathrm{X}$ grade students in SMA Negeri 2 Ungaran who came to UKS with complaints of abdominal pain, weakness, headache before menstruation so can not concentrate when receiving lesson. Meanwhile, based on preliminary study by interviewing 15 students who have menstruation in SMA Negeri 2 Ungaran in February 2017, have experienced or not premenstrual syndrome, the handling done when experiencing premenstrual syndrome and regular menstrual cycle or not. From the interview it was found that 12 had experienced premenstrual syndrome and three girls never experienced premenstrual syndrome. Of the 12 students who had premenstrual syndrome, said taking painkillers available in the UKS, they overcame complaints premenstrual syndrome by lying down, and drinking water. And all of them have regular menstrual cycle that is 2 people with 30 day menstrual cycle and 13 people with 28 day menstrual cycle.

One non-pharmacological alternative to reducingcomplaints premenstrual syndrome is by consuming $68 \mathrm{lb} /$ day isoflavone containing dairy foods at 6 days at the end of thephase luteal because it has an antiestrogenic effect to reduce complaints premenstrual syndrome. This study was aimed to investigate complaints premenstrual syndrome before the consumption of aoflavone-containing food interruption ,complaints premenstrual syndrome after consuming aoflavone distraction and complaints premenstrual syndrome before and after consumption of aoflavonecontaining dairy foods in adolescent girls of class $\mathrm{X}$ in SMA Negeri 2 Ungaran.

\section{METHODS}

This study used pre experiment design using one group pre test-post test design. The sample was taken by simple random sampling totaling 16 respondents. Measurement of complaints premenstrual syndrome using Shorted Premenstrual Assassement Form 1-6. Normality test data used Shapiro-wilk because the total of respondents $<50$, while $\mathrm{p}$ value $>0,05$ which means the normal data distribution and bivariate analysis can be continued using Paired-T test.

\section{RESULT}

\section{Univariate Analysis}

1. Characteristics

Below we will describe the results of the analysis based on the frequency distribution based on the age of the respondents.

Table 1 Frequency Distribution Number of Respondents by Age

\begin{tabular}{|c|c|c|}
\hline Age & Frequency (f) & Percentage (\%) \\
\hline 16 yrs & 12 & 75 \\
\hline 17 yrs & 4 & 25 \\
\hline Total & 16 & 100 \\
\hline
\end{tabular}


2. Complaints Premenstrual Syndrome Before Consumption of Bersoflavone Dairy Foods.

Based on the research conducted the frequency distribution of respondents based oncomplaints premenstrual syndrome in the group interventions are as follows:

Table 2 Distribution of Respondent Frequency Based onComplaints Premenstrual Syndrome Before Consumption of Food Interlude Berisoflavon

\begin{tabular}{|l|c|c|}
\hline Complaints & $\begin{array}{l}\text { Frequency } \\
\text { (f) }\end{array}$ & $\begin{array}{l}\text { Percentage } \\
(\boldsymbol{\%})\end{array}$ \\
\hline Mild & 2 & 12.5 \\
\hline Medium & 14 & 87,5 \\
\hline Total & 16 & 100 \\
\hline
\end{tabular}

Table 3 Descriptive Statistics Based on Complaints Premenstrual Syndrome Before Consumption of Diisoflavone Interlude Foods

\begin{tabular}{|l|l|l|l|l|}
\hline Variable & Mean & \pm SD & Min & Max \\
\hline $\begin{array}{l}\text { Complaints } \\
\text { Premenstrud } \\
\text { syndrome }\end{array}$ & 26.18 & \pm 5.70 & 19 & 38 \\
\hline
\end{tabular}

3. Complaints Premenstrual Syndrome After Consumption of Bersoflavone Dairy Food

Table 4 Frequency Distribution of Respondents Based on Complaints Premenstrual Syndrome After Consumption of Diisoflavone

\begin{tabular}{|l|c|c|}
\hline Complaints & $\begin{array}{c}\text { CleavageCuts } \\
\text { (f) }\end{array}$ & Percentage (\%) \\
\hline Light & 77 & 43.8 \\
\hline Medium & 9 & 56.2 \\
\hline Total & 16 & 100 \\
\hline
\end{tabular}

Table 5 Descriptive Statistics Based onComplaints Premenstrual Syndrome After Consumption of Diisoflavone Interlude Foods

\begin{tabular}{|l|l|l|l|l|}
\hline Variable & Mean & \pm SD & Min & Max \\
\hline $\begin{array}{l}\text { Complaints } \\
\text { Premenstrual } \\
\text { syndrome }\end{array}$ & 21.12 & \pm 3.51 & 14 & 27 \\
\hline
\end{tabular}

\section{Bivariate Analysis}

Table 6 Distribution of Frequency Differences Complaints Premenstrual Syndrome Before and After Consumption of Diisoflavone

\begin{tabular}{|l|c|c|}
\hline Complaints & Before Treatmen & Post Treatment \\
\hline Moderately & 2 & 7 \\
Moderate & 14 & 9 \\
\hline Total & 16 & 16 \\
\hline
\end{tabular}

Table 7 Descriptive $\quad$ Statistics $\quad$ Differences Complaints Premenstrual Syndrome Before and After Consumption of Diisoflavone

\begin{tabular}{|c|c|c|c|c|c|c|c|}
\hline variable & $\begin{array}{l}\text { interve } \\
\text { ntion }\end{array}$ & n & mean & $\begin{array}{l} \pm \\
\text { SD }\end{array}$ & $\begin{array}{l}\text { Mi } \\
\mathbf{n}\end{array}$ & $\begin{array}{l}\text { Ma } \\
\mathbf{x}\end{array}$ & $\begin{array}{l}\mathbf{p} \\
\text { value }\end{array}$ \\
\hline $\begin{array}{l}\text { Premenst } \\
\text { ual } \\
\text { syndrome }\end{array}$ & Pre & 16 & 26.18 & $\begin{array}{l} \pm \\
5.70 \\
6\end{array}$ & 19 & 38 & 0.011 \\
\hline & Post & 16 & 21.12 & $\begin{array}{l} \pm \\
3.51\end{array}$ & 14 & 27 & \\
\hline
\end{tabular}

\section{DISCUSSION}

Based on the frequency distribution and descriptive statistics in table 2 and 3 shows that the average complaints of premenstrual syndrome experienced by respondents before consumption of food containing offlavon drank of 26.18 with median value 25.00 , minimum value of 19.00 and maximum value of 38.00 where standard deviation \pm 5.70 , where those who experienced mild complaints as much as $2(12.5 \%)$, and those with moderate complaints were $14(87.5 \%)$. This proves thatcomplaints premenstrual syndrome experienced by teenage girls are more moderate and not in the weight category according to Andriane, 2011 found in the Journal of America Science which mentions premenstrual syndrome occurring $70 \%$ in women in reproductive and about $30-80 \%$ of women have symptoms premenstrual syndrome moderateand about $2.5 \%$ of women experience premenstrual syndrome with severe symptoms.

Based on the distribution of frequency and descriptive statistic in tables 4 and 5, the mean value of 21.12 , the minimum value of 14 , the maximum value of 27 , and $S D \pm 3.51$, where of all respondents who experienced mild complaints as many as 7 people $(43.8 \%)$ and 9 people $(56.2 \%)$. complaints 
Premenstrual syndrome after a $681 \mathrm{lg}$ / day dose of $68 \mathrm{mg}$ / day dose of $68 \mathrm{mg} /$ day dose for 6 days at the end of the luteal phase indicates a perceived decrease in complaints. This is in line with Kusuma Neela Bolla's 2015 study, entitled Soybean Consumption and Health Benefits, says soy isoflavones are one of the dietary factors associated withcomplexity premenstrual syndrome and are high proteinquality foods.

Based on the results in Table 7 it can be seen that there was a change of the level of complaints before and after treatment. There is a decrease in complaint level premenstrual syndrome seen from the mean value of 26.18 to 21.12 . From the analysis it can be seen that $p$ value $=0.011(\alpha=0.05)$ which means that $\rho$ value $<0.05$, so the hypothesis in this study is accepted where statistically it can be said there are significant differences complaints premenstrual syndrome before and after food consumption a dash of flavones.

Based on the above description of the results of this study in line with previous research conducted by Bryan in 2005 in Cantika Zaddna Year 2014 entitled, "Efect Of Comsumption Of Soy Isoflavones On Behavioral, Somatic And Affective Symptoms N Women With Premenstrual Syndrome" which states the consumption of foods containing oflavones can reduce complaints premenstrual syndrome because they have anti-estrogenic effect. So it can block the hormone estrogen when estrogen levels are excessive and can act as an estrogenic effect when estrogen levels are less.

The decrease in complaints premenstrual syndrome highest after intake of berioflavone intercourse was a complaint of abdominal pain and complaints of back pain, joint pain and muscle or joint stiffness, of which 16 respondents who experienced this complaint there were 6 people who experienced a decrease in this complaint. This is because the consumption of beriosoflavon interlude food is able to stabilize the hormone progesterone and estrogen, so that with the balance of this hormone, will cause uterine contractions and support muscles are also reduced. This is also in line with research conducted by Nahid Golmakami in 2011, titled "Use of Medical Plants in the Treatment of Premenstrual Syndrome" which states the consumption of foods containing oflavones from soy products in which consumption of aoflavone dairy foods, can reduce complaints such as pain in stomach, headache, anxiety, weight gain, easy to forget, and sleep disorders.

While complaints with the decrease in the least amount of only one respondent, there is in the breast complaints of pain and swelling of the breast. This is because these complaints related to fat tissue in the breast and the occurrence of water retention so as to reduce swelling complaints in the breast and legs. In addition, the isoflavones in the body also functioning for fat tissue in the breast is not bound so that the swelling process can be avoided. This is in accordance with the theory that, swelling and pain complaints in the breast $70 \%$ associated with the existing fat tissue in the breast, which is stimulated only $30 \%$ by the hormonal fluctuations before menstruation (Rahmawati, 2011).

In addition, the results of this study also supported research conducted by Michael $P$ Wakeman in 2013 in "An Open-label Pilot Study To Assess The Effectiveness Of Krill Oil With Added Vitamins and Phytonutrients in The Relief Of Symptoms of Premenstrual Syndrome" which states that women who consume foods with phytoetrogens can lower premenstrual syndrome, this is because phytoestrogens contain isoflavones or flavonoids can inhibit cyclooxygenase enzymes that cause inflammatory substances, thereby reducing the incidence of pain and swelling in some parts of the body. Meanwhile, according to Kusuma Neela Bolla 2015, entitled "Soybean Consumption and Health Benefits" states soy isoflavones is one of the food factors associated with the complexity of premenstrual syndrome and is a food with high protein quality so it is beneficial for general health and reproductive health of women special. 


\section{CONCLUSIONS}

Based on the results of the study of $68 \mathrm{bl}$ / day dose of $68 \mathrm{mg} /$ day dose of $68 \mathrm{ozl}$ / day dose for 6 days at the end of the luteal phase, it can reduce complaints premenstrual syndrome in young women. This is because food containing flavonoid compounds can function as an anti-etrogenic effect and estrogenic effect. The results of this study can be used as an intervention in resolving premenstrual syndrome complaints and other complaints during reproductive periods such as: disminorea, and menopause. 


\section{REFERENCES}

Abdurrahman SM, Hiola R, Mursyidah A. Pengaruh Pijat Bayi Terhadap Kualitas Tidur Bayi Di Desa Tabumela Kecamatan Tilango Kabupaten Gorontalo. Jurnal Keperawatan. 2015: 5-18.

Afshar MK, Moghadam ZB, Taghizadeh Z, Bekhradi R, Montazeri A, Mokhtari P. Lavender Fragrance Essential Oil and the Quality of Sleep in Postpartum Women. Iran Red Crescent Med J. 2015;17(4):e25880.

Agusta, Andria. 2000. Aromaterapi, Cara Sehat Dengan Wewangian Alami. Jakarta: Penebar Swadaya.

Aini, Nur dan Kholish N. 2013.Solusi Lengkap Calon Ibu. Yogyakarta: Real Book.

Alimul H, Aziz. 2007. Metode Penelitian Kebidanan \& Teknik Analisis Data.Surabaya: Salemba Medika.

Beider, S. dan Moyer, C.A. 2007.Randomized Controlled Trials of Pediatric Massage.Journal of Pediatric Research: Review, 4(1): 23-34.

Dewi, Iga Prima. (2011). Aromaterapi Lavender Sebagai Media Relaksasi.Bali : Bagian Farmasi Fakultas Kedokteran Universitas Udayana. Diunduh tanggal 18 Agustus 2016.

Dewi, Siska. 2012. Pijat \& Asupan Gizi Tepat Untuk melejitkan Tumbuh Kembag Anak. Yogyakarta: Pustaka Baru Press.

Dieter, J. $d k k$. 2003. Stable Preterm Infants Gain More Weight and Sleep Less after Five Days of Massage Therapy. Journal Of Pediatric Psychology. 28(6): 03-11.

Dinkes Kota Bukittinggi. 2014. Profil Dinas Kesehatan Kota Bukittinggi.

Ford, Gina. 2008. Merawat Dan Membesarkan Bayi 3 Tahun Pertama.Jogjakarta : Garailmu.

Hari S, Wilhelmus. 2012. Statistika \& Aplikasi Untuk Penelitian Ilmu Kesehatan.Jakarta : Trans Info Media.

Hartati T. 2010. Panduan Ibu Hamil Melahirkan \& Merawat Bayi.Jakarta : UBA Press.

Hermawanto, Hery. 2010. Biostatistika Dasar, Dasar-dasar Statistika Kesehatan. Jakarta: Trans Info Media.

Imelda, Rina. 2012. Panduan Kehamilan \& Perawatan Bayi Dari A-Z. Surabaya: Victory.

Indiarti, M.T. 2015. Panduan Terbaik A-Z Kehamilan, Persalinan, dan Perawata Bayi Update dan Terlengkap. Yogyakarta: Indoliterasi.

Kasmiatun Sri.Pengaruh Pijat Bayi Dengan Terapi Lavender Terhadap Pemenuhan Kebutuhan Tidur Neonatus Di Posyandu Melati Mojokerto Kediri. Jurnal Ilmu Kesehatan. Vol. 3, No. 1, November 2014: 41-47.

Kelly, Paula. 2010. Buku Saku Asuhan neonatus \& Bayi.Jakarta: EGC.

Mardiana L, Martini DE.Pengaruh Pijat Bayi Terhadap Kualitas Tidur Bayi Usia 3-6 Bulan Di Desa Munungrejo Kecamatan Ngimbang Kabupaten Lamongan. Surya. Vol.02, No.XVIII, Juni 2014: 109-115.

Marmi dan Rahardjo K. 2012.Asuhan Neonatus, Bayi, Balita, dan Anak Prasekolah. Yogyakarta : Pustaka Pelajar.

Muchtaridi dan Moelyono. 2015. Aroma Terapi;Tinjauan Aspek Kimia Medisinal. Yogyakarta : Graha Ilmu. 
Nanny Lia Dewi, Vivian. 2012. Asuhan Neonatus Bayi dan Anak Balita.Jakarta : Salemba medika.

Pratyahara, Dayu. 2012. Miracle Touch For Your Baby. Jogjakarta: Javalitera.

Primadiati, Rachmi. 2002. Aromaterapi Perawatan Alami Untuk Sehat Dan Cantik. Jakarta: Gramedia Pustaka Utama.

Priyatno, Duwi. 2012. Belajar Cepat Oleh Data Statistik dengan SPSS. Yogyakarta: ANDI.

Proverawati A, Ismawati C. 2010. Berat Badan Lahir Rendah (BBLR). Yogyakarta: Nuha Medika.

Rayyane, Puja. 2013. Buku Pintar Kehamilan \& Perawatan Bayi/Anak Usia Emas. Yogyakarta : Kaldron.

Riksani, Ria. 2012. Cara Mudah \& Aman Pijat Bayi.Jakarta : Dunia Sehat.

Roesli, Utami. 2013. Pedoman Pijat Bayi. Jakarta: Trubus Agriwidya.

Roesli, Utami. 2007. Pedoman Pijat Bayi Prematur \&Usia Bayi 0-3 Bulan. Jakarta: Trubus Agriwidya.

Sadeh Avi. A Brief Screening Questionnaire for Infant Sleep Problems: Validation and Finding for an Internet Sample. Pediatrics. 2014;113;e570.

Saepudin, Malik. 2011. Metodologi Penelitian Kesehatan Masyarakat. Jakarta : Trans Info Media.

Sekartini R, Adi NP. Gangguan Tidur pada Anak Usia Bawah Tiga Tahun di Lima Kota di Indonesia. Sari Pediatri, Vol. 7, No. 4. Maret 2006: 188-193.

Tauman R, Levine A, Avni H, Nehama H, Greenfeld M and Sivan Y. Coexistence of Sleep and Feeding Disturbances in Young Children. Pediatrics.2011;127;e615.I

TriExs. 2012. Ultimate Guide For Your Lovely Baby. Jakarta: TriExs Media.

Tim Galenia MCC. 2014. Home Baby Spa. Jakarta: Penerbit plus+

Walker, Peter. 2011. Panduan Lengkap Pijat Bayi Untuk Merangsang Tumbuh Kembang \& Terapi Kesehatan.Jakarta: PuspaSwara.

Zahler, Kathy A. 2008. 100 Kunci Sukses Mengasuh bayi.Jakarta : Prestasi Pustakarya.

\section{BIOGRAPHY}

First Author Biographies

My name is Ni Wayan Putri Utamai, I was born in Bali. Program D IV Midwifery, Faculty of Health Sciences Ngudi Waluyo University.

Second Author biography

My name is Ida Sofiyanti, I was born in Semarang. Ngudi Waluyo University since 2007 until now.

Third Author biography

My name is Galeh Septiar Pontang, I was born in Semarang. Ngudi waluyo University. 